\title{
LOCATING FLOW-CAPTURING FACLLTIES IN TRANSPORTATION NETWORKS: A FUZZY SETS THEORY APPROACH
}

\author{
Dušan Teodorović ${ }^{1}$, Milica Šelmić \\ 1,2 University of Belgrade, Faculty of Transport and Traffic Engineering, Vojvode Stepe 305, 11000 \\ Belgrade, Serbia
}

Received 19 March 2013; accepted 9 April 2013

\begin{abstract}
Flow-capturing facilities make available service to passing-by client flows. The paper develops a model to determine the locations of the flow-capturing facilities in the transportation network. The objective function to be maximized represents the total client flow intercepted. The basic input data are the estimated numbers of trips between pairs of nodes. It is often impossible to estimate these numbers with enough precision. The estimated numbers of trips are treated in this paper as an uncertain or fuzzy numbers. The concept proposed in the paper is based on fuzzy mathematical programming. The model developed is supported by numerical example.
\end{abstract}

Keywords: flow-capturing facilities, location analysis, fuzzy mathematical programming.

\section{Introduction}

In the majority of problems studied within location analysis, it has been assumed that demand for service is expressed at nodes. Demand at node practically represents node "weight". On the other hand, many clients (drivers) get service if they pass through one of the flow-intercepting facilities (billboards, gasoline stations, fast food, ATMs, day-care units, retail facilities) in the transportation network. In other words, flow-intercepting facilities make available service to passing-by client flows. Every client that passes by such facility is treated as "captured" or "intercepted" client. This paper develops a model to determine the locations of the flow-capturing facilities in the transportation network. The objective function to be maximized represents the total client flow intercepted. The basic input data are the estimated numbers of trips between pairs of nodes. It is often impossible to estimate these numbers with enough precision (i.e. there is a degree of uncertainty surrounding the numbers of trips between pairs of nodes). The paper presents potential application of fuzzy sets theory techniques to a flow-capturing facilities location problem. The model developed is based on the fuzzy mathematical programming. The model is supported by numerical examples.

The paper is organized as follows: Section 2 states the problem, Section 3 proposes a solution to the problem, a numerical example is given in Section 4 and Section 5 presents the concluding remarks.

\section{Statement of the Problem}

Many authors have considered the problem of determining the locations of the flow-

\footnotetext{
${ }^{2}$ Corresponding author: m.selmic@sf.bg.ac.rs
} 
capturing facilities in the transportation network. Different aspects of this problem were treated in the papers of Church and ReVelle (1974), Goodchild and Noronha (1987), Hodgson (1981, 1990), Hodgson and Rosing (1992), Berman et al. (1992), Berman et al. (1995), Berman and Krass (1998), Gendreau et al. (2000), Wu and Lin (2003), Kuby and Lim (2005), and Jun and Min (2006).

Let us consider transportation network $G=$ $(N, A)$ that is represented by a direct graph. This graph includes a set of consecutively numbered nodes $N$, as well as a set of consecutively numbered links $A$. We denote by $n$ cardinality of set $N$. Let us denote by $R$ the set of origins. Let us also denote by $S$ the set of destinations. Each origin-destination pair $r-s$ is connected by a set of travel paths through the network. Let us denote this set by $P_{r s}(r \in R, s \in \mathrm{S})$. The set of all travel paths in the network is denoted by $P$. We denote by $m$ the number of facilities to be located. Let us also introduce the integer variables:

$x_{j}= \begin{cases}1 & \text { iffacility is located at node } j \\ 0 & \text { otherwise }\end{cases}$

$y_{p}= \begin{cases}1 & \text { if there is at least one facility on path } p \\ 0 & \text { otherwise }\end{cases}$

Berman et al. (1992) proposed the following mathematical formulation of the problem of determining the locations of the flowcapturing facilities in the transportation network:

Maximize

$\sum_{p \in P} f_{p} y_{p}$ subject to

$\sum_{j=1}^{n} x_{j}=m$

$\sum_{j \in p} x_{j} \geq y_{p}$ for all $p \notin P$

$x_{j}, y_{p} \in\{0,1\}$

The objective function to be maximized represents the total client flow intercepted. The constraint (2) ensures that the number of facilities located in the network equals $m$. The variable $y_{p}$ equals zero in the case when all the $x_{j}$ for are equal to zero (this means that no one facility is located on path $p$ ).

The problem defined in relations (1) to (4) is NP-hard problem. Various modifications and instances of the problem could be solved by using various optimization and/or heuristic techniques. In order to solve the problem, Berman et al. (1992) proposed branch-andbound, as well as greedy heuristic approaches.

We are most often unable to determine exactly the basic input data-the number of trips between individual pairs of nodes. In other words, there is uncertainty when determining the number of trips between individual pairs of nodes. This paper treats the estimated numbers of trips between individual pairs of nodes as fuzzy numbers. In the problem defined by relations (1) to (4) fuzziness appears due to the lack of ability of exactly predicting certain values.

From this point, we denote by $\boldsymbol{F}_{p}$ the estimated flow along path $p$. The estimated flow values are denoted in bold letters. If, for example, the estimated number of trips along path $p$ is 1000 , this means that we estimate that the number of trips along path $p$ is approximately 1000 (Fig. 1). 
Thus, the problem defined by relations (1) to (4) becomes a problem of fuzzy mathematical programming. Bellman and Zadeh (1970) were the first to consider the possible application of the fuzzy set theory in solving optimization problems. When considering optimization problems in a fuzzy environment, these authors felt that both the objective functions and the constraints that exist in the model could be represented by corresponding fuzzy sets and should be treated in the same manner. Let us assume that there is one or more objective function. We denote by $G$ the fuzzy set that represents the fuzzy domain of the set of objective functions. We also denote by $\boldsymbol{C}$ the fuzzy set that represents the fuzzy domain of the set of constraints. Let fuzzy sets $\boldsymbol{G}$ and $\boldsymbol{C}$ be defined over set $X$. According to Bellman and Zadeh (1970), the fuzzy domain of the decision set is characterized by fuzzy set $\boldsymbol{D}$ whose membership function is:

$\mu_{D}=\min \left\{\mu_{G}(x), \mu_{C}(x)\right\}$

We note that fuzzy set $\boldsymbol{D}$ is the intersection of fuzzy sets $\boldsymbol{G}$ and $\boldsymbol{C}$. In other words, fuzzy set $D$ is the set of solutions to the problem that satisfy both the set of objective functions and the set of constraints.
The problem discussed in this paper can be defined as follows:

For approximately known estimated numbers of trips between individual pairs of nodes, determine the locations of the flow-capturing facilities in the transportation network, so as to maximize the total client flow captured.

\section{Proposed Solution to the Problem}

The problem (P1) is linear integer problem with fuzzy coefficients. When solving linear programming problems in which individual coefficients and/or constraints are fuzzy, Tanaka and Asai (1984) introduced the concept of level of satisfaction $h$. They understood this level of satisfaction (value between 0 and 1) as the level of satisfaction of objective function or the constraint, which is the least satisfied. In other words, the level of satisfaction $h$ comprises a value for which:

$$
\mu_{\mathrm{C}_{i}}(x) \geq h \quad i=1,2, \ldots, C
$$

$$
\mu_{G_{j}}(x) \geq h \quad j=1,2, \ldots, G
$$

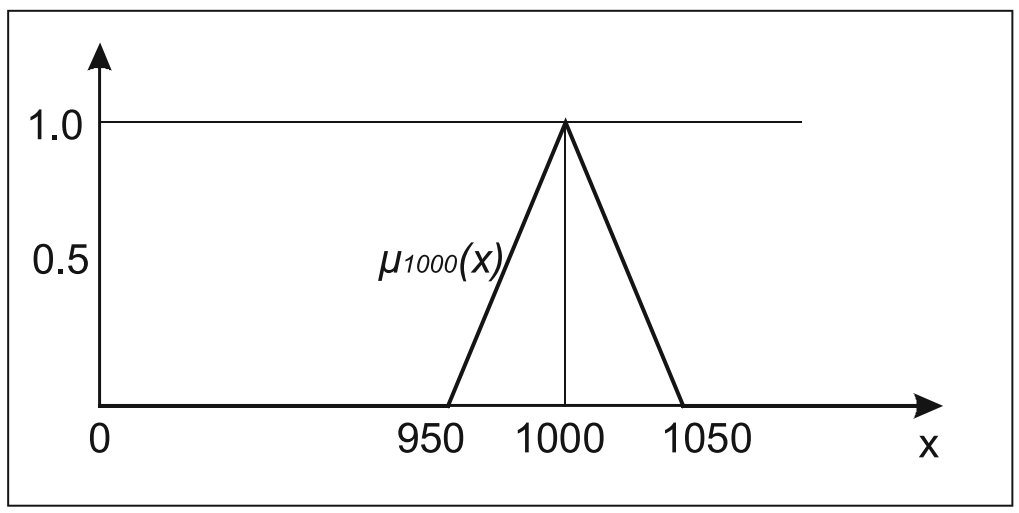

Fig. 1.

Fuzzy Number "Approximate 1,000" 
where:

$\mu_{C_{i}}(\mathrm{x})$ is membership function of the $i$-th

$$
f_{1}=\sum_{p \in P} f_{1 p}{ }^{y} p
$$
constraint

$\mu_{C_{j}}(\mathrm{x})$ is membership function of the $j$-th goal

$C$ is the total number of constraints

$f_{2}=\sum_{p \in P} f_{2 p^{y}} p$

$G$ is the total number of goals.

In our case, fuzziness appears in the

$$
f_{3}=\sum_{p \in P} f_{3 p}{ }^{y} p
$$

objective function $\sum_{p \in P} F_{p} p_{p}$. We treat the coefficients (flows) $\boldsymbol{F}_{p}$ as triangular fuzzy

numbers. The expression $\sum_{p \in P} F_{p} y_{p}$ also represents triangular fuzzy number. We will denote this number by $\boldsymbol{F}=\left(f_{1}, f_{2}, f_{3}\right)$. Values $f_{1}$, $f_{2}$, and $f_{3}$ are determined based on the known left boundaries, $f_{1 p}$, average values, $f_{2 p}$, and right boundaries, $f_{3 p}$, of fuzzy numbers $\boldsymbol{F}_{\boldsymbol{p}}$ $(p=1,2, \ldots)$ using the rules of fuzzy arithmetic. These values equal:

Fig. 2 presents the membership function of fuzzy number $\boldsymbol{F}$.

Based on the similarities of the corresponding triangles, it is easy to show that the highest value of the objective function for level of satisfaction $h$ equals $f_{3}-h\left(f_{3}-f_{2}\right)$. It would be logical to try to "shift" this value as much to the right as possible. In other words, the initial problem $(\mathrm{P} 1)$ is transformed into the following problem:

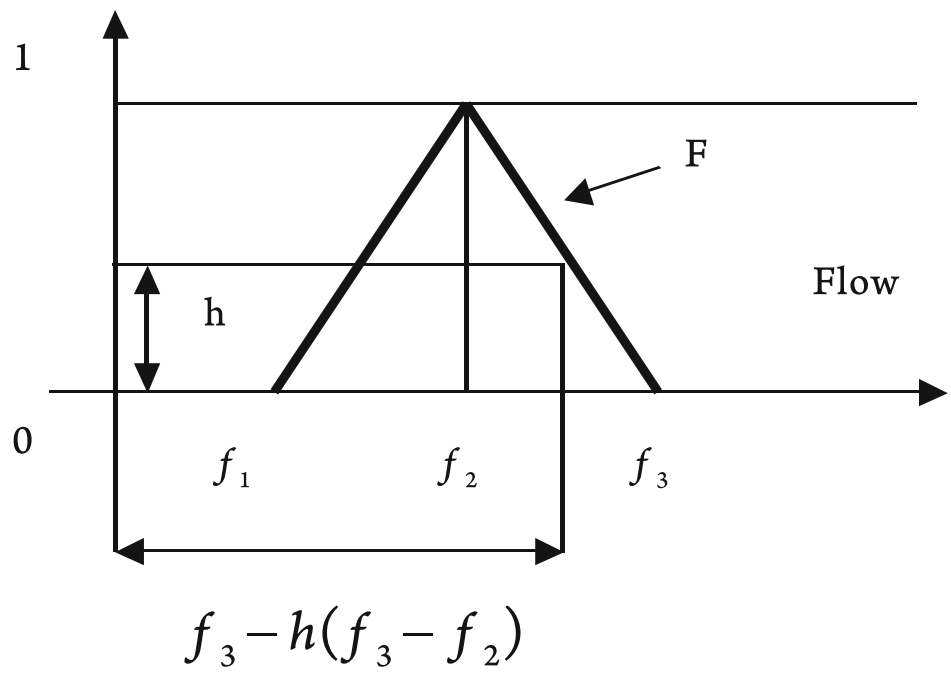

\section{Fig. 2.}

Membership Function of Fuzzy Number F Representing Objective Function 
(P2)

Maximize

$$
f_{3}-h\left(f_{3}-f_{2}\right)
$$

subject to

$$
\sum_{j=1}^{n} x_{j}=m
$$

$\sum_{j \in p} x_{j} \geq y_{p}$ for all $p \notin P$

$x_{j}, y_{p} \in\{0,1\}$

In this case, the solution is obtained by previously defining the value of level of satisfaction $h$.

\section{Numerical Examples}

We tested the proposed approach with the transportation network shown in the Fig. 3.
There are 10 nodes in the considered transportation network. We assumed that clients exclusively use first two shortest paths between any node pair. We varied the number of facilities $m$ located in the network. The cases when $m=2$, and $m=4$ are shown in the Table 1, and in the Fig. 4 and Fig. 5. We used Optimization Programming Language 3.5 in order to solve the problem (P2).

\section{Table 1}

Dependence of the Total Client Flow

Captured on the Level of Satisfaction $h$

\begin{tabular}{|l|l|l|}
\hline & \multicolumn{2}{|l|}{ The total client flow captured } \\
\hline $\boldsymbol{h}$ & 2 facilities & 4 facilities \\
\hline 0.0 & 10661 & 13812 \\
\hline 0.1 & 10565.8 & 13684.6 \\
\hline 0.2 & 10470.6 & 13557.2 \\
\hline 0.3 & 10375.4 & 13429.8 \\
\hline 0.4 & 10280.2 & 13302.4 \\
\hline 0.5 & 10185 & 13175 \\
\hline 0.6 & 10090 & 13048 \\
\hline 0.7 & 9995 & 12921 \\
\hline 0.8 & 9900 & 12794 \\
\hline 0.9 & 9805 & 12667 \\
\hline 1.0 & 9710 & 12540 \\
\hline
\end{tabular}

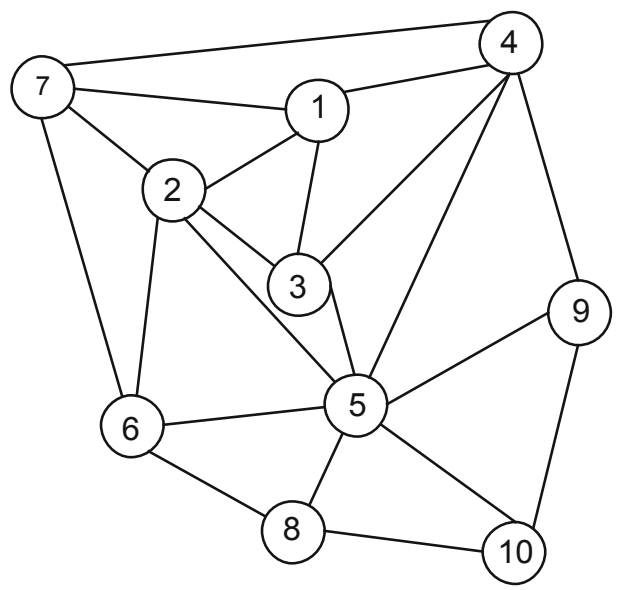

Fig. 3.

Considered Transportation Network 


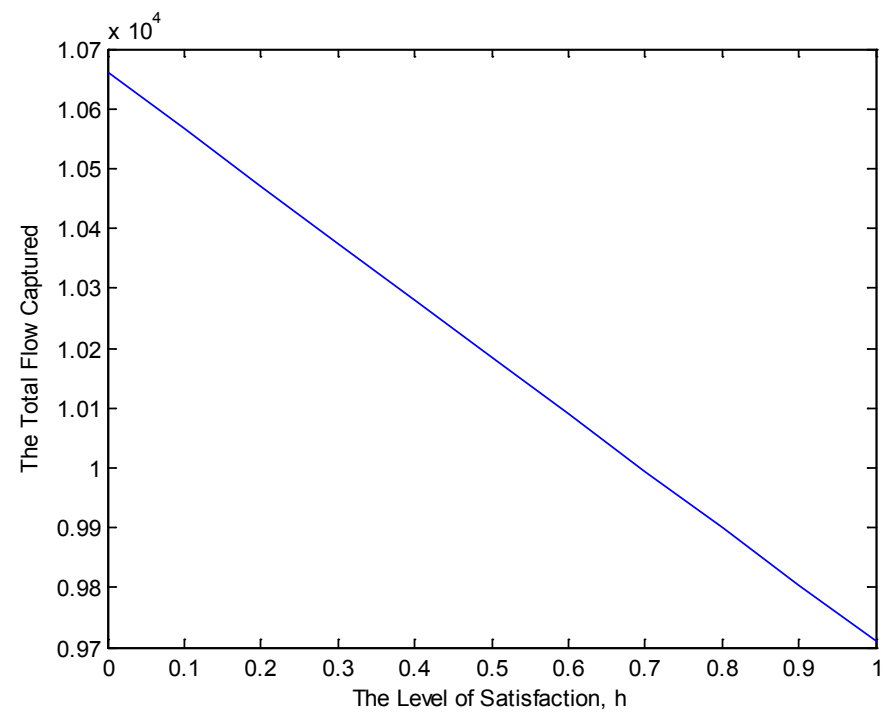

Fig. 4.

Dependence of the Total Flow Captured (2 Facilities) on the Level of Satisfaction $h$

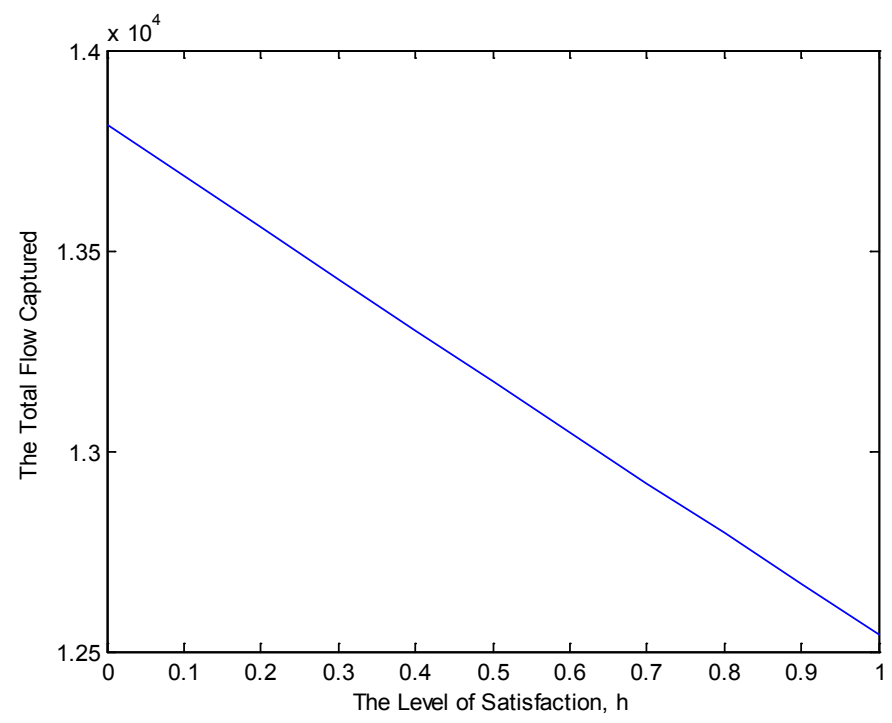

Fig. 5.

Dependence of the Total Flow Captured (4 Facilities) on the Level of Satisfaction $h$ 
Every pair (Level of satisfaction, Total flow captured) corresponds to a specific decision. In this manner, a large number of different potential decisions are generated for the decision maker. We also studied the dependence of the total number of facilities $m$ on the total flow captured. The obtained results (for the case when $h=0.9$ ) are shown in the Table 2, and in the Fig. 6.

\section{Table 2}

Dependence of the Total Flow Captured on the Total Number of Facilities $(h=0.9)$

\begin{tabular}{|l|l|l|}
\hline \multicolumn{2}{|l|}{$\mathbf{h = . 9}$} \\
\hline $\begin{array}{l}\text { Number of } \\
\text { facilities }\end{array}$ & $\begin{array}{l}\text { The total client } \\
\text { flow captured }\end{array}$ & $\begin{array}{l}\text { Optimal facility } \\
\text { locations }\end{array}$ \\
\hline 1 & 6886 & 5 \\
\hline 2 & 9805 & 4,5 \\
\hline 3 & 11949 & $2,4,5$ \\
\hline 4 & 12667 & $2,4,5,6$ \\
\hline 5 & 12970 & $2,4,5,7,8$ \\
\hline 6 & 13113 & $1,2,4,5,6,10$ \\
\hline 7 & 13113 & $1,2,4,5,6,8,10$ \\
\hline 8 & 13113 & $1,2,4,5,6,7,8,9$ \\
\hline 9 & 13113 & $1,2,4,5,6,7,8,9,10$ \\
\hline 10 & 13113 & $1,2,3,4,5,6,7,8,9,10$ \\
\hline
\end{tabular}

\section{Conclusion}

Flow-capturing facilities make available service to passing-by client flows. Every client that passes by such facility is treated as "captured" or "intercepted" client. This paper develops a model to determine the locations of the flow-capturing facilities in the transportation networks. The basic input data when searching for the optimal locations of the flow-capturing facilities are the estimated flows between individual pairs of nodes. This paper does not develop a special model to evaluate flows between individual pairs of nodes; rather it is assumed that flows comprise the input values. It is assumed in the paper that we only know the approximate flows between individual pairs of nodes. The uncertainty regarding the number of trips is clearly more pronounced when the estimated number refers to several years in advance.

This paper developed a model to determine the locations of the flow-capturing facilities in transportation networks. The objective

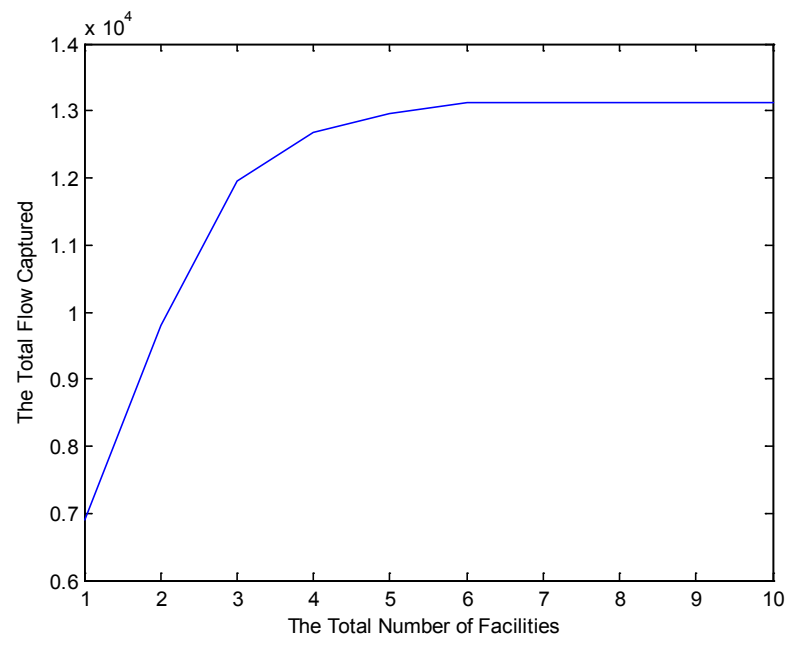

Fig. 6.

Dependence of the Total Flow Captured on the Total Number of Facilities $(h=0.9)$ 
function to be maximized represents the total client flow intercepted. The estimated numbers of trips between pairs of nodes are treated in this paper as an uncertain or fuzzy numbers. The proposed model is based on the fuzzy sets theory. By applying fuzzy linear programming, the optimal facility locations were discovered.

We studied the dependence of the level of satisfaction on the total flow captured. We also studied the dependence of the total number of facilities on the total flow captured. The model developed generates a large number of various potential decisions for the decision maker.

By varying the width of the triangular fuzzy numbers that represent the estimated number of trips between pairs of nodes, it is possible to discover various facility locations. The wider of the fuzzy numbers correspond to a higher level of our uncertainty regarding the number of trips. In other words, by applying the developed model it is possible to obtain various facility locations depending on the level of our certainty in the estimated number of trips.

The proposed model could be expanded and modified in future research in a few ways. The proposed approach for solving the flow-capturing facilities location problem in a fuzzy environment could also incorporate the competition that exists between the facilities. The multi-objective approach to the studying problem seems also important and challenging research topic.

\section{Acknowledgements}

This research was supported by the Ministry of Science of Serbia, Grant Number 36002.

\section{References}

Bellman, B.; Zadeh, L. 1970. Decision making in a fuzzy environment, Management Science. DOI: http://dx.doi. org/10.1287/mnsc.17.4.B141, 17(4): 144-164.

Berman, O.; Krass, D. 1998. Flow intercepting spatial interaction model: a new approach to optimal location of competitive facilities, Location Science. DOI: http://dx.doi. org/10.1016/S0966-8349(98)00047-3, 6(1-4): 41-65.

Berman, O.; Krass, D.; Xu, C.W. 1995. Locating discretionary service facilities based on probabilistic customer flows, Transportation Science. DOI: http://dx.doi. org/10.1287/trsc.29.3.276, 29(3): 276-290.

Berman, O.; Larson, R.C.; Fouska, N. 1992. Optimal location of discretionary service facilities, Transportation Science. DOI: http://dx.doi.org/10.1287/trsc.26.3.201, 26(3): 201-211.

Church, R.L.; ReVelle, C.S. 1974. The maximum covering location problem, Papers of Regional Science. DOI: http:// dx.doi.org/10.1111/j.1435-5597.1974.tb00902.x, 32(1): 101-118.

Gendreau, M.; Laporte, G.; Parent, I. 2000. Heuristics for the Location of Inspection Stations on a Network, Naval Research Logistics. DOI: http://dx.doi.org/10.1002/ (SICI) 1520-6750(200006) 47:4<287::AID NAV2>3.0.CO;2-R, 47(4): 287-303.

Goodchild, M.F.; Noronha, V.T. 1987. Location-allocation and impulsive shopping: The case of gasoline retailing. In: Ghosh, A., Rushton, G. (Eds.), Spatial Analysisand LocationAllocation Models, Van Nostrand Reinhold, New York. 121-136.

Hodgson, M.J. 1990. A flow-capturing location-allocation model, Geographical Analysis. DOI: http://dx.doi. org/10.1111/j.1538-4632.1990.tb00210.x, 22(3): 270-279. 
Hodgson, M.J. 1981. The location of public facilities intermediate to the journey to work, European Journal of Operational Research. DOI: http://dx.doi. org/10.1016/0377-2217(81)90208-3, 6(2): 199-204.

Hodgson, M.J.; Rosing, K.E. 1992. A network locationallocation model trading off flow capturing and p-median objectives, Annals of Operations Research. DOI: http://dx.doi. org/10.1007/BF02060480, 40(1): 247-260.

Jun, Y.; Min, Z. 2006. Flow Capturing Location-allocation Problem with Piecewise Linear Value-Time Function Based on Max-min Ant Colony Optimization. In Proceedings of the IEEE International Conference on Computational Intelligence and Security, Guangzhou, China. 1172-1175.

Kuby, M.; Lim, S. 2005. The flow-refueling location problem for alternative-fuel vehicles, Socio-Economic Planning Sciences. DOI: http://dx.doi.org/10.1016/j. seps.2004.03.001, 39(2): 125-145.

Tanaka, H.; Asai, K. 1984. Fuzzy linear programming problems with fuzzy numbers, Fuzzy Sets and Systems. DOI: http://dx.doi.org/10.1016/0165-0114(84)90022-8, 13(1): 1-10.

Wu, T.H.; Lin, J.N. 2003. Solving the competitive discretionary service facility location problem, European Journal of Operational Research. DOI: http://dx.doi. org/10.1016/S0377-2217(01)00391-5, 144(2): 366-378.

\section{LOCIRANJE OBJEKATA KOJI OPSLUŽUJU KLIJENTE U SAOBRAĆAJNOM TOKU - PRIMENA TEORIJE FAZI SKUPOVA}

\section{Dušan Teodorović, Milica Šelmić}

Sažetak: Svaki klijent koji prolazi pored objekta se smatra "uhvaćenim" klijentom i na taj način biva opslužen. U ovom radu je razvijen model za određivanje lokacije objekata koji pružaju svoje usluge klijentima u saobraćajnom toku. Kriterijumskom funkcijom se teži da se maksimizira broj "uhvaćenih", odnosno, opsluženih klijenata. Osnovni ulazni podaci su vrednosti tokova između parova čvorova. Često je nemoguće precizno odrediti ove veličine, te se zbog toga približna vrednost veličine toka tretira kao fuzzy broj. Predloženi koncept u ovom radu se svodi na tehniku fuzzy matematičkog programiranja. Razvijeni model je testiran kroz numerički primer.

Ključne reči: objekti koji opslužuju klijente u saobraćajnom toku, lokacijska analiza, fazi matematičko programiranje. 